\title{
EDUCATION PROGRAMMES' RESPONSIBILITIES REGARDING PERVASIVE SKILLS
}

\author{
Monique Strauss-Keevy* \\ University of Johannesburg \\ mstrauss@uj.ac.za
}

Received: May 2013

Accepted: February 2014

\begin{abstract}
The Competency Framework of the South African Institute of Chartered Accountants (SAICA) details specific competencies, but also places emphasis on the pervasive skills that need to be attained by candidates in order to qualify as South African chartered accountants (CAs (SA)). This article presents the results of a literature review and empirical work that provides conflicting results as to whether the education, the training or a combination of the programmes are responsible for ensuring that aspirant $C A s(S A)$ are equipped with pervasive skills. This study returned significant findings, indicating that SAICA-accredited academics are not aware of their responsibility to ensure that aspirant CAs (SA) have achieved all the competencies as set out in SAICA's Competency Framework. While this apparent shortcoming may exist, it is the responsibility of the Heads of Academic Departments and SAICA alike to further inform academics that the onus to transfer both competencies (specific and pervasive) rests predominantly with them.
\end{abstract}

Keywords

Academic programme, Academics, Chartered Accountant, Competency Framework, Delivery, Education programme, Pervasive skills, SAICA, Transfer, Training programme

Ms M Strauss-Keevy is a senior lecturer in the Department of Accountancy, University of Johannesburg, South Africa. 


\title{
1. INTRODUCTION
}

In 2008, the South African Institute of Chartered Accountants (hereafter SAICA) released its Competency Framework (International Federation of Accountants (hereafter IFAC), 2010b:7/8). The Competency Framework detailed the specific competencies that aspirant Chartered Accountants (hereafter CAs) needed to achieve, and placed specific emphasis on pervasive skills. The competencies in the Competency Framework formed the foundation of SAICA's new qualification model, on which SAICA's accredited education and training programmes are based (Coetzee, Joubert, \& Oberholzer, 2009:16; SAICA, 2009:12). Barac (2009:20) has added to this by conveying that "a framework of this kind provides a foundation on which education, training and final assessment are delivered and developed".

With the release of the Competency Framework, there was an important shift in emphasis on the skills required of aspirant CAs. Previously, the education programme was based on a knowledgebased syllabus (SAICA, 2009:4), which was input-driven rather than an output-based (Cargill, Gammie \& Hamilton, 2010:28). With the inclusion of pervasive skills, the new SAICA qualification model conveys the following message (SAICA 2009:9):

\begin{abstract}
Qualification as a CA (SA) is not merely related to competence. It is also the culmination of education, training and assessment processes aimed at assessing the combination of intellect, aptitude and the ability to respond to demanding situations. Intellectual ability and the ability to apply oneself are as important as competence (pervasive, specific) as it is these abilities which contribute to the ability of the CA (SA) to be a life-long learner and to respond to a fast-changing environment. It is these abilities which enable the CA (SA) to be successful in a wide range of demanding work environments.
\end{abstract}

The above extract conveys the point that education, training and assessment are required in order for candidates to perform the work necessary of a CA (SA). The education programme is provided by SAICA-accredited academics in the form of an undergraduate degree, followed by a postgraduate degree (SAICA, 2009:8; SAICA, 201la:3, 8). Once candidates have successfully completed the education programme, they will be assessed in the Initial Test of Competence (hereafter ITC), which focuses on the assessment of knowledge, skills and professional values, and does not rely on the practical experience gained by candidates during the training programme (SAICA, 2009:8; SAICA, 201la:3, 8). Taking cognisance of this, the ITC will assess not only specific competencies, but also pervasive skills. Consequently, academics will be expected to ensure that candidates are competent in this regard.

The pervasive skills are divided into three categories, namely ethical behaviour and professionalism (IA), personal attributes (IB) and professional skills (IC) (SAICA, 2009:6, 9). At the outset, it is important to define the three categories of pervasive skills in the context of the Competency Framework, as they are core to this article (SAICA 2009:12):

IA - Ethical Behaviour and Professionalism: The CA profession is committed to maintaining the confidence of clients, employers and the public through an overriding commitment to integrity in all professional tasks. Thus, all CAs are expected at all times to abide by the highest standards of integrity; they must be, and must be seen to be, carrying out all assignments objectively and independently, in accordance with the ethical values outlined in detail in Section I of the Competency Framework.

IB Personal Attributes: CAs are expected to develop a number of personal qualities that shape the way they conduct themselves as professionals. These qualities or attributes are outlined in Section II of the Competency Framework. 
IC Professional Skills:CAs are also expected to develop a wide range of professional skills that, while not unique to the CA profession, are critical to its successful practice. These skills are outlined in Section III of the Competency Framework.

As mentioned earlier, in 2008 SAICA released its Competency Framework. However, only in early 2010 was another document titled "Detailed Guidance Document for Academic Programmes" released by SAICA. This gave more detailed information on the three categories of pervasive skills required (SAICA, 2010a:4). In terms of the pervasive skills, the Detailed Guidance Document for Academic Programmes included two principal instructions to academics. The first instruction, which concerns category $\mathrm{IA}$ and $\mathrm{IB}$, conveyed the notion that academics are "expected to address all those qualities and skills, which, in their opinion, are suitable for inclusion in the academic programme". The second instruction, relating to category IC, averred that academics are "to address all appropriate professional skills in the academic programme". In both cases academics will be required to explain how these qualities and skills are addressed and provide full motivation for excluding any from the education programme (SAICA, 2010a:12). Consequently, SAICA-accredited academics were tasked to address pervasive skills as set out in SAICA's Competency Framework in their education programmes.

During May 2011, SAICA released a draft document to the Heads of Academic Departments (hereafter HODs) titled "Guidelines for the Part I of the Qualifying Examination - Assessment of Core (Technical) Competence". This document informed academics that the ITC is based on the premise that candidates do not have practical work experience, and thus the education programme is more responsible than the training programme for ensuring that candidates are competent in these areas (SAICA, 201la:7).

Furthermore, in SAICA's draft of the new accreditation criteria, relating to SAICA's new qualification model, SAICA expressed the view that HODs would have to attest that all competencies in the Competency Framework were assessed during the education programmes, and that the assessment was done comprehensively (SAICA, 2011b:35-37). In its new accreditation criteria, SAICA once again states that the onus rests on academics to ensure that all competencies are transferred to candidates during the education programme.

Furthermore, it must be acknowledged that globally very little research has been conducted on the delivery of pervasive skills (Boritz \& Carnaghan, 2003:7; Paisey \& Paisey, 2004:1, as quoted in Kirstein \& Plant, 2011:4). Likewise, in South Africa (hereafter SA) this topic is somewhat unfamiliar in the realms of accounting research (Kirstein \& Plant, 2011:4). Coetzee and Stegman (2011:12) have posited in the two accredited SA accountancy research journals, namely the $S A$ Journal of Accounting Research and Meditari Accountancy Research, that only $5 \%$ and $3.2 \%$ of research in SA is performed on ethics and professionalism, and personal attributes and professional skills respectively.

The remainder of this article is structured as follows: the next section presents the objective of the study. The sections that follow describe the theoretical framework of the paper, the research methodology and the empirical findings and the results. Conclusions and recommendations drawn from this study are presented in the last section.

\section{OBJECTIVE AND LIMITATION OF THE STUDY}

The objective of the study is twofold: firstly, to determine, using a literature review, whether the education or the training or a combination of the programmes are responsible for the delivery of 
pervasive skills during aspirant CAs' qualification model; and, secondly, it aims to provide empirical evidence by means of a questionnaire to solicit the views of SAICA's accredited academic providers by addressing the following questions: What programmes are responsible for the delivery of pervasive skills? Which vehicles most effectively result in the acquisition/development of pervasive skills? Lastly, which vehicles most effectively result in the assessment of pervasive skills?

The study has the limitation that the focus is on SAICA's accredited academic providers. Consequently, the findings might not be representative of the views of non-SAICA accredited academic providers.

\section{LITERATURE REVIEW}

In the literature there is a variety of research specifically related to IFAC, the qualification models of the Chartered Accountants' Group of Eight (hereafter CAGE), the qualification models of other accounting bodies and research performed in the accounting profession as to whether the education, the training or a combination of the programmes are responsible for the transfer of pervasive skills during aspirant CAs' qualification model. The findings are presented in the sections below.

\subsection{IFAC}

IFAC has expressed the view that pervasive skills, referred to as professional skills and professional values, ethics and attitudes, are more important than a knowledge base (IFAC, IES2, 2010a:39/40, 54). Accordingly, there are increased expectations that these competencies are becoming ever more present in the accounting profession.

IFAC defines education as: "the systematic process aimed at acquiring and developing knowledge, skills and other capabilities within individuals", whereas training is defined as the "learning and development activities that complement education and practical experience" (IFAC, Framework, 2010a:14). IFAC argues that certain pervasive skills are transferred more effectively during the training programme (IFAC, IES 6, 2010a:65). In addition to this statement, IFAC has remarked that the training programme ultimately facilitates candidates in demonstrating competence of professional knowledge, professional skills and professional values, ethics and attitudes (IFAC, IES6, 2010a:66).

In contrast to this, IFAC expresses the view that professional values, ethics and attitudes, should be included early in the education programme and should continue as part of life-long learning (IFAC, IES4, 2010a:54). This view is reiterated in the accounting profession (Cargill et al., 2010:30; Hill \& Milner, 2008, as quoted in Milner \& Stoner, 2010:124). Moreover, IFAC has noted that, with reference to the education and the training programmes, not "any one route on its own" can result in candidates being equipped with competencies (IFAC, 2003:24).

As far back as 2002, IFAC expressed the view that academics and IFAC member bodies have a shared responsibility to ensure that education programmes are of a high standard and quality. Furthermore, these programmes should encourage future professional accountants to adapt to change; and, in doing so, academics and IFAC member bodies must be responsive to the constantly changing environment (IFAC, 2002:4). 


\subsection{CAGE member bodies}

In light of SAICA's reciprocity agreements and its desire to retain its reciprocity status with CAGE member bodies (SAICA, 2010b), attention was also given to these bodies' incorporation of pervasive skills in their qualification models.

Like IFAC and SAICA, CAGE member bodies have also moved away from a purely knowledge-based syllabus to qualification models inclusive of both specific competencies and pervasive skills (Canadian Institute of Chartered Accountants (hereafter CICA), 2002:1; Institute of Chartered Accountants in Ireland (hereafter ICAI), 2010; Institute of Chartered Accountants of Scotland (hereafter ICAS), $2011: 4$; Institute of Chartered Accountants in Australia (hereafter ICAA), 2011; Institute of Charted Accountants in England and Wales (hereafter ICAEW), 2010a:3; ICAEW, 2010b:5; Hong Kong Institute of Certified Public Accountants (hereafter HKICPA), 2011:1/2, 8; New Zealand Institute of Chartered Accountants (hereafter NZICA), 2011a).

Similarly to IFAC, CAGE member bodies have mixed views as to whether the education programme, the training programme or a combination of the programmes results in the delivery of pervasive skills to aspirant CAs.

For ICAA, the education and the training programmes are completed simultaneously. Therefore, both programmes are important to the attainment of pervasive skills (ICAA, 2010). CICA agrees with this view, as only at the end of both the education and the training programmes are candidates expected to demonstrate all of the pervasive skills. Consequently, the entire qualification route is necessary to transfer all the CA competencies (CICA, 2011). This view is also affirmed by ICAI, which has asserted that the integration of the education and training elements results in candidates being equipped with pervasive skills (Cargill et al., 2010:36; ICAI, 2011).

HKICPA averred that before entering the training programme, candidates should have obtained pervasive skills (HKICPA, 2011:4, 15/16). ICAS believes that classroom lectures are the most effective method for candidates to apply competencies to a work situation (ICAS, 2010). Accordingly, this is where pervasive skills are transferred. In addition, ICAEW has the view that "the education system is the foundation on which every profession builds its quest for excellence and service" (ICAEW, 2002:2). In contrast to this, NZICA conveys the view that the education programme merely results in the transfer of technical knowledge and consequently only includes the transfer of specific competencies (NZICA, 201lb), while the training programme includes the delivery of both specific competencies and pervasive skills (NZICA, $2011 c)$.

\subsection{Accounting profession}

In recent years, accounting bodies' qualification models have also moved away from purely technical knowledge to include pervasive skills. Some of these bodies include: the American Institute of Certified Public Accountants (hereafter AICPA), the Association of Chartered Certified Accountants (hereafter ACCA) and the Chartered Institute of Management Accountants (hereafter CIMA) (AICPA, 2010:1; ACCA, 2011:2; CIMA, 2010:71/72).

Globally in the accounting profession there are also diverse views as to whether education programmes alone result in the transfer of pervasive skills. Hyland has indicated that a university education is where pervasive skills are naturally developed (Hyland, 1994, as quoted in Gammie \& Kirkham, 2008:362), while Howieson (2003:70) argues that "universities are ideally 
placed, if they are so inclined, to offer the sorts of generic, life-long learning skills that will be essential for success in a world of rapid change". Furthermore, Brown and McCartney (1995:44) remark that "competences into the accounting education is intended to work outwards from the professional bodies into the syllabuses that can be applied by staff at academic institutions".

Others have asserted that a combination of the education and the training programmes is crucial to the development of CAs (Allison, 1997:1, as quoted in Paisey \& Paisey, 2001:29):

\footnotetext{
Chartered accountants of the future will need to exhibit skills gathered from the workplace and core knowledge gathered from the education process. It is not possible either to gather all skills and knowledge from only the workplace, nor ... to gather all skills and knowledge required from only a simulated education system.
}

Similarly, professional accountants need to complete examinations and demonstrate workplace experience (ACCA, 2008, as quoted in Cargill et al., 2010:53). Gammie and Lines (2004:11, 124) are of the opinion that not all competencies can be assessed at a university level, as certain competencies can only be assessed in the work environment. Others have agreed with this view by stating that pervasive skills are more easily addressed in the workplace (Garent, 1997, Raelin, 2000, Hancock, Howieson, Kavanagh, Kent, Tempone \& Segal, 2009 and Jackling \& DeLange, 2009, as quoted in Cargill, 2010:16, 25). Likewise, Deppe and Hardy (1995:61/62) affirm that certain skills can be attained only after the completion of the training programme.

In a study performed by Berry, Lotter, Shuttleworth and Viviers, University of South Africa (hereafter UNISA) third-year accounting students were asked about the effectiveness of Open Distance Learning institutions in equipping them with pervasive skills. Berry et al. noted that students who simultaneously work and study are more satisfied with the attainment of pervasive skills than students who only study. Thus, workplace environments supplement classroom teaching (Berry et al., 2011:2/3, 10, 13, 15-19).

In his study of undergraduate accounting students in the Thuthuka programme at the University of Johannesburg (hereafter UJ), Vandiar averred that pervasive skills are transferred throughout the education programme (Vandiar, 2010:22, 28, 39, 42). Likewise, Streng's study of accounting students in the Thuthuka programme at $U J$ also provided evidence that the majority of the pervasive skills are developed during the education programme (Streng, 2011:ii, 59, 88/89).

There are also diverse views with regard to ethical behaviour and values and whether these can actually be addressed during the education programme (Stape, 2002, as quoted in Cooper, Dellaportas, Jackling \& Leung, 2007:932), or whether they can be delivered only during the training programme when candidates are faced with ethical dilemmas (Petrecca, 2002, as quoted in Cooper et al., 2007:932). Collison and Gray $(2002: 798,827)$ are of the view that ethical issues, morals and environmental matters are not easily incorporated into education programmes. However, in disagreement with this, and as far back as 1964, it was argued that business ethics could be taught in an accounting programme (Loeb \& Rockness, 1992:486, as quoted in Els, 2007:176). In addition, Cooper, Dellaportas, Jacking, Leung and Wong (2008:408) conveyed the notion that an education programme can result in improved ethical awareness and decision-making. Jennings (2004:18) is of the opinion that incorporating ethics into an education programme is not a difficult task. Universities should merely "refocus in the content of ethics training" by providing mechanisms to cope with the pressures placed on accountants, which will result in "ethical leadership in business".

Clikeman and Henning asserted that incorporating ethics education into the curriculum influences candidates' professional attitudes (Clikeman \& Henning, 2000, as quoted in Cooper et 
al., 2007:933) and increases their awareness of ethical issues (McDonald \& Donleavy, 1995, as quoted in Cooper et al., 2008:408/409). Furthermore, students who are studying accounting or business degrees are less likely to behave unethically. The behaviour they portray during the education programme will be carried forward to the workplace in the future, and thus there is a need for ethics teaching during the education programme (Malone, 2006:145).

On the other hand, Flemming (1996:215) expressed the view that universities alone cannot be responsible for equipping candidates with ethical values and behaviours. The American Accounting Association (hereafter AAA) posits that values, ethics and attitudes cannot be taught or assessed during educational programmes (AAA, n.d.:Section 9.6). In addition, it has been argued that workplace environments have a bigger impact on the development of ethical behaviour and professionalism (Wimbush \& Shepard, 1994, as quoted in Cooper et al., 2007:928/929). Conversely, Malone provides evidence that moral thinking is developed early in life and thus ethics cannot be taught in a classroom setting (Pakaluk, 2005, as quoted in Malone, 2006:145/146).

Two studies were conducted on the views of IFAC's member bodies on ethics education. Member bodies had to rank their agreement with certain statements on a four-point Likert scale, where one indicated "strongly disagrees", two "disagrees", three "agrees", and four "strongly agrees". When member bodies were asked about their agreement with the following statement: "ethics should be learned as a life-long learning development", an aggregate mean score of 3.5 was indicated. However, an aggregate mean score of only 1.6 was indicated when member bodies were asked whether "moral standards of students are fully developed and can't be changed or improved with education". In addition to this, aggregate mean ratings of 3.5 and 3.2 respectively were indicated for the member bodies for the following two statements: "ethics should be learned as part of the pre-qualifying programs" and "ethics should be learned just like other technical accounting issues" (IFAC, 2006:40; Cooper et al., 2007:939). It is evident from both studies that IFAC's member bodies view ethics education as an important part of the education programme, and will continue as part of life-long learning.

In Bampton and Cowton's study (2002:282, 288), accounting lecturers in the British Isles were asked whether ethics in university education can improve students' ethical attitudes, values and behaviours. Only $20 \%$ of lecturers expressed the view that ethics education plays an important role in this regard. Moreover, the same lecturers were asked which of the following were responsible for ethics education: family, religious groups, schools, universities, business or the profession. Religious groups ranked the lowest, university and business tied second lowest, while family was considered the most important factor and the profession the second most important factor in driving ethics education.

Amid this debate, Adkins and Radtke (2004:284, 286, 288/289) posed questions to accounting students and faculty members in the United States on their perceptions on the inclusion of an ethics course at university to assist in solving moral and ethical issues faced in the accounting profession and the business community. Their study indicated that $66.2 \%$ of students and $59.1 \%$ of faculty members felt that an ethics course at university could solve moral and ethical issues.

\section{RESEARCH METHODOLOGY}

The research problem was addressed by following a two-pronged approach. Firstly, an extensive literature review pertaining to SAICA, IFAC, CAGE member bodies' qualification models, other 
accounting bodies' qualification models and research in the accounting profession revealed that there are diverse views pertaining to the transfer of pervasive skills during the education, the training or a combination of the programmes. Secondly, this was followed by empirical work that solicited the views of SAICA-accredited academics on the effectiveness of programmes during SAICA's qualification model in addressing the pervasive skills. It is ultimately these individuals who will be responsible for ensuring that aspirant CAs (SA) are equipped with all competencies before they sit for the ITC, and are therefore well positioned to comment on the transfer of pervasive skills.

The literature review was conducted up until the end of December 2011. The empirical work, which formed the next phase of the study, was performed subsequent to this date.

\subsection{Research instrument}

A web-based questionnaire was administered to academics providing instruction to aspirant CAs (SA) at SAICA's academic programmes regarding their views of the effectiveness of the education, the training and a combination of the programmes in the attainment of pervasive skills. This entailed emailing the link to the web-based questionnaire to participants. The use of a questionnaire as the research instrument in this paper follows the approach commonly used when obtaining the perceptions of a large number of participants (Coetzee, 2004:7.2). The questions in the questionnaire were based on the information gleaned from the literature as presented above. The questionnaire consisted of three sections of mostly closed-ended questions of a quantitative nature. Comments boxes were included at the end of each section, which comprised the qualitative aspect of the questionnaire.

Section one solicited the views of academics on the extent to which pervasive skills can be transferred during the education and training programmes. A Likert-scale-type question was used in this section (TABLE 5.1). Sections two and three sought the perceptions of academics on the effectiveness of vehicles in acquiring/developing (TABLE 5.2) and assessing (TABLE 5.3) pervasive skills respectively. In both of these sections participants had to rank certain vehicles that could be applied in the transfer of competencies.

\subsection{Population}

The empirical study focused on all academics, providing instruction to aspirant CAs (SA) at SAICA's accredited academic programmes. This included academics from the following accredited programmes: Accounting Professional Training, Monash South Africa, Nelson Mandela Metropolitan University, North West University, Rhodes University, University of Cape Town, University of Fort Hare, University of Free State, UJ, University of KwaZulu-Natal, University of Limpopo, University of Pretoria, UNISA, University of Stellenbosch, University of the Western Cape and University of Witwatersrand (SAICA, 2012:3-12). It is the HODs from these programmes that will have to attest to SAICA how their courses have equipped aspirant CAs (SA) with pervasive skills.

In certain instances, academics at these accredited programmes provide instruction at both an undergraduate and postgraduate level; similarly, certain academics provide instruction on more than one subject area. As a consequence of this, it was not possible to sub-divide the population into sub-strata. Therefore, all academics were included in the empirical study and a census was accordingly conducted. 


\subsection{Ethical requirements}

The HODs from SAICA's accredited academic programmes were contacted. Permission to email the link to the questionnaire to the academics at their institutions was obtained. Furthermore, participants were notified of the following in the email, in order to ensure that ethical considerations were followed in this study (Exactica, 2010):

- the purpose of the study;

- that the questionnaire was not obligatory;

- that participants could refrain from answering any particular question(s);

- that data collected in this study would be kept confidential and would be used only in aggregating results.

\subsection{Response rate}

The response rate was $32.3 \%$. The response rate is higher than other web-based questionnaires performed in SA (Eiselen \& Nkoutchou, 2012:37). Furthermore, response rates as low as $10 \%$ are common when an onsite questionnaire is used (Economic and Social Research Council, 2012), while Marx (2009:31) has expressed the view that questionnaire response rates in SA vary between $25 \%$ and $38 \%$. Thus the response rate of $32.3 \%$ is considered sufficient for the purpose of this study, and has been presented in Table 4.1 below.

TABLE 4.1 Response rate

\begin{tabular}{lcc}
\hline & Number & $\%$ \\
\hline Total emails dispatched containing the link to the questionnaire & 443 & 100.0 \\
Uncompleted questionnaires & 300 & 67.7 \\
Completed questionnaires & 143 & 32.3 \\
\hline
\end{tabular}

Source: Author's analysis

It must be noted that none of the questions in the questionnaire were compulsory, and participants could refrain from answering a particular section, or a question (or questions) in a section. For that reason, participants did not necessarily answer all of the questions. Therefore, the totals will not always agree with the completed questionnaires figure of 143 as indicated above. This will be noticeable for certain sections or questions, depending on whether or not participants answered the questions.

\section{PURPOSE OF THE QUESTIONNAIRE}

As already conveyed in the literature review, there are varied opinions on whether or not pervasive skills can be transferred during the education programme, or whether the training programme is favoured in this regard. However, SAICA has stipulated that all pervasive skills must be addressed in the education programmes of academics, and HODs will have to provide a reason for the exclusion of any one of the competencies, as set out in the Competency Framework. As a result, the questionnaire solicited the views of academics on the effectiveness 
of the programmes during SAICA's qualification model in equipping candidates with pervasive skills. The results of the questionnaire will be presented in section $5.1,5.2$ and 5.3 below.

\subsection{Academics' overall views on the programmes responsible for the delivery of pervasive skills}

In the first section of the questionnaire, a five-point Likert scale was used and participants were asked to rate the statements concerning academics' overall views on the delivery of pervasive skills, as presented below: 1 = do not agree at all; 2 = agree to a lesser extent; 3 = agree to $a$ moderate extent; 4 = agree to a large extent; and 5 = agree completely.

TABLE 5.1: Academics' overall views on the programmes responsible for the delivery of pervasive skills:

\section{$\begin{array}{lllllllll}1 & 2 & 3 & 4 & 5 & n & \text { WAM } & \text { Md } & S D\end{array}$}

1. Pervasive skills can be taught at university, similar to

specific competencies

$9 \begin{array}{lllllllll}9 & 27 & 64 & 36 & 7 & 143 & 3.03 & 3.00 & 0.945\end{array}$

2. Lecturers at university are best suited to deliver pervasive skills to aspirant CAs (SA)

3. Students can attain $\begin{array}{llllllllll}\text { professional competence at } & 24 & 43 & 45 & 27 & 4 & 143 & 2.61 & 3.00 & 1.062\end{array}$ university

4. Training programmes offered during the practical experience period are best suited to deliver pervasive skills to aspirant CAs (SA)

5. The education programme and the training programme culminate in the attainment of professional competence

\section{Source: Author's analysis}

Key: WAM = Weighted arithmetic mean; $M d=$ Median; and SD = Standard deviation

With regard to question one, the majority of academics (71\%) either "agreed to a moderate extent" or to a "large extent" that pervasive skills can be taught at university. However, only $5 \%$ of academics "agreed completely" with the question. Similarly, in question two, the majority of academics (36\%) did not feel that lecturers are best suited to deliver pervasive skills. Conversely, only $2.8 \%$ of academics "agreed completely" with the second question. There are also diverse views as to whether students can attain professional competence at university, as indicated by the mixed selection of options by academics and a mean score of only 2.61. Once again, only $2.8 \%$ of academics "agreed completely" with the statement "students can attain professional competence at university". The first three questions provide evidence that the 
majority of academics are of the view that the education programme is not best suited for the transfer of pervasive skills. This is supported by the low mean scores for the first three questions respectively: $3.03,2.61$ and 2.61 .

In comparison, for question four academics are of the opinion that the training programme is more suited in this regard, as indicated by the high mean score of 4.20 . Furthermore, the majority of academics (43.4\%) "agreed completely" that the training programme is best suited to transfer pervasive skills. For question five, the majority of academics (68\%) either "agreed completely" or "agreed to a large extent" that the education programme and the training programme culminate in the attainment of professional competence. Academics' perceptions on the five questions above are in agreement with their views as set out below in TABLE 5.2 and TABLE 5.3.

A valuable comment was received from one of the academics in the comments box at the end of the section: equipping candidates with pervasive skills "requires detailed pedagogical planning which I don't think we as CAs (SA) (or equivalent) are sufficiently prepared to teach at times".

Nevertheless, SAICA has expressly stated that academics are expected to address all of the CA competencies. Even though not all academics "agreed completely" that pervasive skills can be taught at university, as with specific competencies, academics are still expected to address these competencies during their education programmes.

\subsection{Academics' views on the vehicles that most effectively result in the acquisition/ development of pervasive skills}

In section two, academics were asked the following question: which vehicles most effectively result in the acquisition/development of pervasive skills. Participants were asked to rank the effectiveness of certain vehicles. The ranking was from 1 (most effective) to 5 (least effective), and participants could use each number only once. The results of the section are set out in Table 5.2 , and are presented from the most effective to the least effective based on the weighted arithmetic mean.

TABLE 5.2 Academics' views on the vehicles that most effectively result in the acquisition/ development of pervasive skills $(n=140)$ :

\begin{tabular}{|c|c|c|c|c|c|c|}
\hline & $I^{s t}$ & $2^{\text {nd }}$ & $3^{d}$ & $4^{\text {th }}$ & $5^{\text {th }}$ & M \\
\hline $\begin{array}{l}\text { Combination of the education and training } \\
\text { programmes }\end{array}$ & 47 & 27 & 35 & 21 & 10 & 2.43 \\
\hline $\begin{array}{l}\text { Training programmes en route to qualifying as a CA } \\
\text { (SA) }\end{array}$ & 28 & 51 & 32 & 19 & 10 & 2.51 \\
\hline Post-qualification (working as a CA (SA)) & 33 & 27 & 22 & 44 & 14 & 2.85 \\
\hline $\begin{array}{l}\text { SAICA-accredited education programmes en route to } \\
\text { qualifying as a CA (SA) }\end{array}$ & 30 & 17 & 29 & 29 & 35 & 3.16 \\
\hline Continuing professional development & 2 & 18 & 22 & 27 & 71 & 4.05 \\
\hline
\end{tabular}

Source: Author's analysis

Key: $M=$ Weighted Arithmetic Mean 
TABLE 5.2 shows that academics are of the opinion that a combination of the education and the training programmes most effectively results in the acquisition/development of pervasive skills (mean $=2.43$ ). The second and third most effective vehicles are perceived to be the training programme (mean $=2.51)$, followed by post-qualification (mean $=2.85)$. Ranked only in fourth place is the education programme (mean $=3.16)$.

The following three comments were made by academics in the comments box at the end of the section. These comments may shed some light on the low ranking of the education programme by academics:



Post-qualification (working as a CA (SA)) was ranked highly by academics, while Continued Professional Development (hereafter CPD) was ranked in last position. It would be expected that both of these should have been ranked in either fourth or fifth position; considering that these take place after qualification as a CA (SA). At entry into the profession, candidates are expected to have attained all of SAICA's competencies. Furthermore, during post-qualification (working as a CA (SA)), candidates would use the competencies in their work environment, while CPD allows CAs (SA) to maintain competence.

\subsection{Academics' views on the vehicles that most effectively result in the assessment of pervasive skills}

As with the previous section, the views of academics regarding the vehicles that most effectively result in the assessment of pervasive skills were solicited. In addition to the vehicles included in the section above, are SAICA's ITC and its Assessment of Professional Competency (hereafter $A P C)$. Participants were asked to rank the effectiveness of the vehicles, and the ranking was from 1 (most effective) to 7 (least effective) and participants could use each number only once. The results are set out in Table 5.3, and are presented from the most effective to the least effective based on the weighted arithmetic mean scores.

TABLE 5.3 Academics' views on the vehicles that most effectively result in the assessment of pervasive skills:

\begin{tabular}{lcccccccc}
\hline & $1^{\text {st }}$ & $2^{\text {nd }}$ & $3^{\text {d }}$ & $4^{\text {th }}$ & $5^{\text {th }}$ & $6^{\text {th }}$ & $7^{\text {th }}$ & $M$ \\
\hline $\begin{array}{l}\text { Training programmes en route to } \\
\text { qualifying as a CA (SA) }\end{array}$ & 34 & 31 & 23 & 17 & 17 & 17 & 2 & 3.08 \\
$\begin{array}{l}\text { Combination of the education and } \\
\text { training programmes }\end{array}$ & 29 & 18 & 31 & 26 & 19 & 10 & 6 & 3.30 \\
$\begin{array}{l}\text { Post-qualification (working as a CA } \\
\text { (SA)) }\end{array}$ & 37 & 17 & 14 & 14 & 11 & 30 & 16 & 3.71
\end{tabular}




\begin{tabular}{lcccccccc}
\hline & $1^{\text {st }}$ & $2^{\text {nd }}$ & $3^{\text {d }}$ & $4^{\text {th }}$ & $5^{\text {th }}$ & $6^{\text {th }}$ & $7^{\text {th }}$ & $M$ \\
\hline $\begin{array}{l}\text { SAICA-accredited education } \\
\text { programmes en route to qualifying as }\end{array}$ & 22 & 17 & 22 & 22 & 24 & 11 & 22 & 3.93 \\
$\begin{array}{l}\text { a CA (SA) } \\
\text { SAICA's Initial Test of Competence }\end{array}$ & 7 & 22 & 23 & 20 & 34 & 15 & 19 & 4.24 \\
$\begin{array}{l}\text { SAICA's Assessment of Professional } \\
\text { Competence }\end{array}$ & 9 & 16 & 16 & 28 & 21 & 31 & 19 & 4.46 \\
$\begin{array}{l}\text { Continuing professional development } \\
\text { N }\end{array}$ & 3 & 19 & 11 & 13 & 13 & 25 & 55 & 5.22 \\
\hline
\end{tabular}

Source: Author's Analysis

Key: $M$ = Weighted Arithmetic Mean

The vehicles perceived to be most effective in the assessment of pervasive skills paint a very similar picture to the vehicles of acquisition/development (TABLE 5.2). Ranked in first position by academics is the training programme (mean $=3.08$ ). A combination of the education and the training programmes (mean $=3.30$ ) is ranked in second place, followed by post-qualification (mean $=3.71$ ) in third place. The education programme, similarly to the results for acquisition/development methods (TABLE 5.2), is ranked in fourth position (mean = 3.93).

Post-qualification (working as a CA (SA)) was ranked highly by academics (third), while CPD was ranked in last position, as it was with acquisition/development (section 5.2). As already noted in the previous section, at entry point into the profession, candidates are expected to have been assessed on all of the pervasive skills.

SAICA's ITC and APC are ranked in only sixth and fifth position respectively. This result is expected, given that aspirant CAs (SA) should have been equipped with the pervasive skills before they sit for the ITC and APC.

\section{CONCLUSIONS AND RECOMMENDATIONS}

The purpose of this study was to provide insight into the views of SAICA-accredited academics on the transfer of pervasive skills during their education programmes. From a SAICA perspective, it emerged that the responsibility for the transfer of all competencies rests more with academics during their education programmes than during the training programme.

However, a significant concern was the results of the empirical research, which suggest that academics view the training programme and post-qualification (working as a CA (SA)) as more effective in the transfer of pervasive skills than the education programme. Furthermore, another concern is that the majority of academics are of the opinion that lecturers are not best suited to deliver pervasive skills to aspirant CAs (SA).

From this is it clear that a greater awareness needs to be created among academics that the onus for the delivery of pervasive skills rests predominantly on them. It is therefore recommended that HODs at SAICA-accredited academic programmes should emphasize to academics that the task of ensuring that candidates are equipped with competencies rests largely on them. Furthermore, there is obviously a misconception among academics that they 
are not ultimately responsible for equipping candidates with all competencies prior to the ITC. Thus, SAICA should be stronger in its message that the responsibility for the transfer of all competencies rests with academics during the education programme.

Regardless of the challenges faced by universities, academics should develop innovative methods to address the transferring of pervasive skills during their education programmes.

\section{LIST OF REFERENCES}

Adkins, N. \& Radtke, R.R. (2004). Students' and faculty members' perceptions of the importance of business ethics and accounting ethics education: is there an expectations gap? Journal of Business Ethics, 51(3), pp. 279-300.

American Accounting Association (AAA) (n.d.). Assessing for the new curriculum: A guide for professional accounting programs. [Online] Available:

http://aaahq.org/aecc/assessment/intro.htm. (Accessed 18 August 2011).

American Institute of Certified Professional Accountants (AICPA) 2010. Mapping of the AICPA core competency framework to the skills tested on the CPA exam. [Online] Available:

http://www.aicpa.org/InterestAreas/AccountingEducation/Resources/CurriculumDevelopment/Core CompetencyFrameworkandEducationalCompetencyAssessmentWebSite/DownloadableDocuments/Ma pping_of_CCF_to_CPA_Exam_Skills_forAEC.pdf. (Accessed 30 March 2011).

Association of Chartered Certified Accountants (ACCA) 2011. ACCA syllabus June and December 2011. [Online] Available: http://www2.accaglobal.com/documents/complete_sg2011.pdf. (Accessed 14 December 2011).

Bampton. R. \& Cowton, C.J. (2002). Pioneering in ethics teaching: The case of management accounting in universities in the British Isles. Teaching Business Ethics, 2, pp. 279-295.

Barac, K. (2009). South African training officers' perceptions of the knowledge and skills requirements of entry-level trainee accountants. Meditari Accountancy Research, 17(2), pp. 19-46.

Berry, P., Lotter, M., Shuttleworth, B. \& Viviers, G. (2011). Graduates perceptions of open distance learning management accounting students. Conference proceedings: Southern African Accounting Association, Fancourt, South Africa, 26-29 June 2011.

Boritz, J.E. \& Carnaghan, C.A. (2003). Competency-based education and assessment for the accounting profession: A critical review. Canadian Accounting Perspectives, 2(1), pp. 7-43.

Brown, R.B. \& McCartney, S. (1995). Competence is not enough: meta-competence and accounting education. Accounting Education, 4(1), pp. 43-53.

Canadian Institute of Chartered Accountants (CICA) 2002. CA Professional Education Guidelines for Specified Programs. [Online] Available: http://www.cica.ca/become-aca/documents/item 10345.pdf. (Accessed 30 March 2010).

Canadian Institute of Chartered Accountants (CICA) 2011. CA skills and competencies. [Online] Available: http://www.cica.ca/become-a-ca/ca-skills-and-competencies/index.aspx. (Accessed 6 July 2011).

Cargill, E., Gammie, E. \& Hamilton, S. (2010). Searching for good practice in the development and assessment of non-technical skills in accountancy trainees - a global study. Aberdeen, Scotland: The Robert Gordon University. 
Chartered Institute of Management Accountants (CIMA) 2010. CIMA 2010 Syllabus. [Online] Available:

http://www.cimaglobal.com/Documents/Student $\% 20$ docs/2010\%20syllabus\%20docs/2010\%20Sylla bus.pdf. (Accessed 12 July 2011).

Coetsee, D. \& Stegman, N. (2011). A profile of accounting research in South African accounting journals. Conference proceedings: Southern African Accounting Association, Fancourt, South Africa, 26-29 June 2011.

Coetzee, M. (2004). The fairness of affirmative action: an organisational justice perspective. Doctorate Thesis. Pretoria: University of Pretoria.

Coetzee, S., Joubert, B. \& Oberholzer, R. (2009). Tax topics a trainee chartered accountant should be taught: a survey of perceptions in and outside public practice. Meditari Accountancy Research, 17(1), pp. 15-31.

Collison. D. \& Gray, R. (2002). Can't see the wood for the tree, can't see the trees for the numbers? Accounting education, sustainability and the public interest. Critical Perspectives on Accounting, 13, pp. 797-836.

Cooper, B.J., Dellaportas, S., Jackling, B. \& Leung, P. (2007). Professional accounting bodies' perceptions of ethical issues, causes of ethical failure and ethics education. Managerial Auditing Journal, 22(9), pp. 928-944.

Cooper, B.J., Dellaportas, S., Jacking, B., Leung, P. \& Wong, G. (2008). Ethics education for accounting students - a toolkit approach. Accounting Education: An International Journal, 17(4), pp. 405-430.

Deppe, L.A. \& Hardy, J.W. (1995). A competency-based, integrated approach to accounting education. Accounting Education, 4(1), pp. 55-75.

Economic and Social Research Council (2012). Advantages and disadvantages of online questionnaires. [Online] Available: http://www.restore.ac.uk/orm/questionnaires/quesads.htm. (Accessed 10 February 2012).

Eiselen, R. \& Nkoutchou, H. (2012). Retirement saving behaviour of young adults in the financial services sector. Journal of Economic and Financial Sciences, April 2012, (5), pp. 31-48.

Els, G. (2007). Utilising continued professional development of ethics amongst prospective chartered accountants. Doctoral Thesis. Johannesburg: University of Johannesburg.

Exactica. (2010). Volume 9. The dissertation bulletin. Questionnaires (Part One). Email to: tlvoogst@uj.ac.za.From: exactica@majesticinteractive.co.za, 8 March 2010.

Flemming, A.I.M. (1996). Ethics and accounting education in the UK - a professional approach? Accounting Education, 5(3), pp. 207-217.

Gammie, E. \& Kirkham, L. (2008). Breaking the link with a university education in the creation of a chartered accountant: The ICAS story. The British Accounting Review, 40, pp. 356-375.

Gammie, $\varepsilon . \&$ Lines, D. (2004). Assessment methods report to the education committee of the International Federation of Accountants. Aberdeen, Scotland: The Robert Gordon University.

Hong Kong Institute of Certified Public Accountants (HKICPA) 2011. Information paper on enhancements. [Online] Available:

http://appl.hkicpa.org.hk/oldsite/students(NEW)/download/qp/info_paper.pdf. (Accessed 19 October 2011). 
Howieson, B. (2003). Accounting practice in the new millennium: is accounting education ready to meet the challenge? The British Accounting Review, 35, pp. 69-103.

Institute of Chartered Accountants Australia (ICAA) 2010. How to become a chartered accountant. [Online] Available:

http://www.charteredaccountants.com.au/students/the_chartered_accountants_program/becomi ng_achartered_accountant. (Accessed 3 August 2010).

Institute of Chartered Accountants Australia (ICAA) 2011. Demonstrating competency. [Online] Available: http://www.charteredaccountants.com.au/Candidates/The-Chartered-AccountantsProgram/Practical-experience/Demonstrating-competency. (Accessed 20 October 2011).

Institute of Chartered Accountants of England and Wales (ICAEW) 2002. Global business development: Challenges for accountancy education. London: Centre for Business Performance.

Institute of Chartered Accountants of England and Wales (ICAEW) 2010a. ACA advanced stage syllabus 2010. [Online] Available:

http://www.icaew.com/index.cfm/route/159744/icaew_ga/Students/ACA_students/Exams/ACA_Ad vanced_Stage_syllabus_2010/pdf. (Accessed 28 July 2010).

Institute of Chartered Accountants of England and Wales (ICAEW) 2010b. ACA professional stage syllabus 2010. [Online] Available:

http://www.icaew.com/index.cfm/route/157728/icaew_ga/Students/ACA_students/Exams/ACA_Pro fessional_Stage_syllabus_2010/pdf. (Accessed 28 July 2010).

Institute of Chartered Accountants of Ireland (ICAI) 2010. New Syllabus. [Online] Available: http://www.charteredaccountants.ie/Students/Student-Services/Courses/New-Syllabus/. (Accessed 28 July 2010).

Institute of Chartered Accountants of Ireland (ICAI) 2011. Acquiring and demonstrating competency. [Online] Available: http://www.charteredaccountants.ie/Students/Student-Services/Courses/NewSyllabus/Key-Competencies/. (Accessed 20 October 2011).

Institute of Chartered Accountants of Scotland (ICAS) 2010. The CA qualification revealed. [Online] Available: http://www.ca-training.co.uk/AboutCATraining/CAQualificationRevealed.aspx. (Accessed 23 July 2010).

Institute of Chartered Accountants of Scotland (ICAS) 2011. ICAS syllabus 2010/2011. [Online] Available: http://www.icas.org.uk/site/cms/download/CAED/caed_syllabus_20010_1l.pdf. (Accessed 20 0ctober 2011).

International Federation of Accountants (IFAC) 2002. Recognition of pre-certification education providers by IFAC member bodies. [Online] Available: http://www.ifac.org/publicationsresources/iep-1-recognition-pre-certification-education-providers-ifac-member-bodies. (Accessed 29 September 2011).

International Federation of Accountants (IFAC) 2003. Towards competent professional accountants. [Online] Available: http://www.ifac.org/sites/default/files/publications/files/iep-2-towardscompetent.pdf. (Accessed 29 September 2011).

International Federation of Accountants (IFAC) 2006. Approaches to the development and maintenance of professional values, ethics and attitudes in accounting education programmes. [Online] Available: http://www.accountingweb-cgi.com/whitepapers/approaches_to.pdf. (Accessed 29 September 2011). 
International Federation of Accountants (IFAC) 2010a. Handbook of International Education Pronouncements. [Online] Available: http://web.ifac.org/publications/international-accountingeducation-standards-board/handbook. (Accessed 23 September 2010).

International Federation of Accountants (IFAC) 2010b. Program Components. [Online] Available: http://www.ifac.org/ComplianceProgram/. (Accessed 22 February 2011).

Jennings, M.M. (2004). Incorporating ethics and professionalism into accounting education and research: A discussion of the voids and advocacy for training in seminal works in business ethics. Issues in Accounting Education, 19(1), pp. 7-26.

Kirstein, M. \& Plant, K. (2011). Action research in audit education: South African teachers' perspectives. Conference proceedings: Southern African Accounting Association, Fancourt, South Africa, 26-29 June 2011.

Malone, F.L. (2006). The ethical attitudes of accounting students. The Journal of American Academy of Business, 8(1), pp. 142-146.

Marx, B. (2008). An analysis of the development, status and functioning of audit committees at large listed companies in South Africa. Doctoral Thesis. Johannesburg: University of Johannesburg.

Milner, M. \& Stoner, G. (2010). Embedding generic employability skills into an accounting degree: Development and impediments. Accounting Education: an International Journal, 19(1-2), pp. 123138.

New Zealand Institute of Chartered Accountants (NZICA) 2011a. How to become a Chartered Accountant. [Online] Available:

http://www.nzica.com/Join\%20us/How\%20to\%20become\%20a\%20member/Chartered\%20Accountan t.aspx. (Accessed 9 March 2011).

New Zealand Institute of Chartered Accountants (NZICA) 2011b. Academic requirements for admission. [Online] Available:

http://www.nzica.com/Join\%20us/How\%20to\%20become\%20a\%20member/ Where $\% 20$ and $\% 20$ what $\% 20$ to $\% 20$ study/Academic $\% 20$ requirements $\% 20$ for $\% 20$ membership.aspx. (Accessed 9 March 2011).

New Zealand Institute of Chartered Accountants (NZICA) 2011 c. Professional competence programme. [Online] Available:

http://www.nzica.com/Join\%20us/How\%20to\%20become\%20a\%20member/ Professional\%20Competence\%20Programme.aspx. (Accessed 9 March 2011).

Paisey, C. and Paisey, N.J. (2001). A comparative study of undergraduate and professional education in the professions of accountancy, medicine, law and architecture. [Online] Available:

http://www.icas.org.uk/site/cms/download/res_Paisey_Comparative_Study_of_Undergrad_2001. pdf. (Accessed 5 July 2011).

South African Institute of Chartered Accountants (SAICA) 2009. Competency Framework. Competencies of a Chartered Accountant (SA) at entry point to the profession. [Online] Available: https://saica.co.za/Portals/0/Documents/CompetencyframeworkCAs.pdf. (Accessed 8 March 2010).

South African Institute of Chartered Accountants (SAICA) 2010a. Detailed Guidance for Academic Programmes. [Online] Available:

http://www.saica.co.za/Portals/0/documents/FINAL_Detailed_Guidance_for_the_academic programme_(Nov_2009).pdf. (Accessed 14 October 2010). 
South African Institute of Chartered Accountants (SAICA) 2010b. New CA(SA) training programme to benefit the SA economy. [Online] Available:

https://www.saica.co.za/tabid/695/itemid/1952/language/en-ZA/New-CASA-training-programmeto-benefit-SA-econom.aspx. (Accessed 15 0ctober 2010).

South African Institute of Chartered Accountants (SAICA) 2011a. Guidelines for the Part I of the Qualifying Examination - Assessment of Core (Technical) Competence (Revisions from 2013). Email to:moniquestrauss@gmail.com. From: anathik@saica.co.za, 16 February 2011.

South African Institute of Chartered Accountants (SAICA) 201lb. Accreditation Criteria for Academic Programmes.Email to: mstrauss@uj.ac.za.From: mandio@saica.co.za, 29 September 2011.

South African Institute of Chartered Accountants (SAICA) 2012. List of SAICA accredited programmes 2012. [Online] Available:

https://www.saica.co.za/Portals/0/LearnersStudents/documents/List\%20of\%20 accredited\%20programmes\%202012.pdf. (Accessed 30 March 2012).

Streng, J.P. (2011). An evaluation of the Thuthuka $\rho E I$ Programme based on the SAICA competency framework and syllabus. Master's dissertation. Johannesburg: University of Johannesburg.

Vandiar, T. (2010). An evaluation of the Thuthuka undergraduate programme based on the skills identified in the SAICA Competency Framework. Master's dissertation. Johannesburg: University of Johannesburg. 